\title{
Differential Regulation of Lymphokine Production by Distinct Subunits of the T Cell Interleukin 2 Receptor
}

\author{
Stefan Burdach, * Norbert Zessack," Dagmar Dilloo, * Margaret Shatsky, ${ }^{*}$ Diana Thompson," and Lee Levitt* \\ *Department of Pediatric Hematology/Oncology, Heinrich Heine University Medical Center, 4000 Dusseldorf 1 , \\ Federal Republic of Germany; and the ${ }^{\ddagger}$ Division of Hematology, Department of Medicine, Stanford University Medical Center, \\ Stanford, California 94305
}

\begin{abstract}
Most biologic responses to IL-2 have been attributed to interaction of IL-2 with a high affinity receptor which consists of a heterodimer composed of two distinct IL-2-binding proteins (IL-2R $\alpha /$ IL-2R $\beta$ ). However, both low affinity IL-2R $\alpha$ (55 kD) and intermediate affinity IL-2R $\beta(70-75 \mathrm{kD})$ also appear to be expressed independently on the cell surface. We investigated the receptor-specific regulatory effects of IL-2 on cytokine production in unstimulated and activated $T$ cells. $T$ cells were activated by stimulation of the antigen receptor complex with antiCD3 mAb. IL-2 $\left(10^{2} \mathrm{U} / \mathrm{ml}, 1 \mathrm{nM}\right)$ stimulation of resting cells resulted in a fivefold increase in GM-CSF release but in only minimal IFN-gamma release. IL-2 markedly augmented mRNA expression of GM-CSF but not IFN-gamma in unstimulated $T$ cells. IL-2R $\beta$ mAb but not IL-2R $\alpha$ mAb decreased IL-2-induced GM-CSF release and mRNA expression from unstimulated $T$ cells. IL-2 concentrations required for GMCSF release from resting cells suggested ligand binding to an intermediate affinity receptor. GM-CSF and IFN-gamma release from activated $T$ cells increased four- to fivefold in response to 1 nM IL-2 and IL-2 augmented both GM-CSF and IFN-gamma mRNA. IL-2R $\beta$ mAb but not IL-2R $\alpha$ mAb reduced GM-CSF release and mRNA expression in activated T cells stimulated with 1 nM IL-2. IL-2R $\alpha$ blockade markedly decreased IL-2-induced IFN-gamma release and mRNA expression from activated cells, while IL-2R $\beta$ blockade had little effect on IFN-gamma production in activated cells. IL-2R $\alpha$ blockade altered the affinity of the receptor mediating activated cell GM-CSF release from a high affinity to an intermediate affinity state. These studies indicate an independent role for IL-2R $\beta$ in mediating GM-CSF production from $T$ cells. They also suggest that unstimulated and activated $T$ cells, which express distinct IL-2 receptor moieties, mediate release of separate lymphokines and that different subunits of the IL-2 receptor may play an important role in the regulation of cytokine production. (J. Clin. Invest. 1991. 87:2114-2121.) Key words: granulocyte-macrophage colony stimulating factor $\bullet$ interferon
\end{abstract}

Address correspondence and reprint requests to Dr. Stefan Burdach, Universitates-Kinderlinik, Moorenstr. 5, D-4000 Dusseldorf 1, FRG, or to Dr. Lee Levitt, Room S-161, Hematology Division, Stanford University Medical Center, Stanford, CA 94305.

Received for publication 8 May 1990 and in revised form 29 January 1991.

J. Clin. Invest.

(c) The American Society for Clinical Investigation, Inc. $0021-9738 / 91 / 06 / 2114 / 08 \quad \$ 2.00$

Volume 87, June 1991, 2114-2121

\section{Introduction}

IL-2 is a well characterized lymphokine that modulates immunologic responses in a variety of leukocyte populations including T cells, natural killer cells, myeloid cells, and B cells $(1,2)$. Cellular responses induced by IL-2 are mediated by the interaction of the protein with its specific receptor. Two surface IL-2-binding proteins have been identified on human $\mathrm{T}$ cells (1, 3-8): a $55 \mathrm{kD}$ chain (IL-2R $\alpha$ ) with low IL-2 affinity, which is upregulated after $T$ cell activation, and a 70-75- $\mathrm{kD}$ chain (IL-2R $\beta$ ) with intermediate affinity, which is present on a small percent of resting $T$ cells and on activated $T$ cells. The high affinity IL-2 receptor consists of both the 55 and $70-75-\mathrm{kD}$ chain. It can be upregulated upon activation of $T$ lymphocytes by antigen presentation to the $T$ cell antigen receptor complex. Additionally, IL-2 has been shown to modulate expression of its own receptors on $\mathrm{T}$ cells $(9,10)$.

Simultaneous interaction of IL-2 with both subunits of the high affinity IL-2 receptor on T cells has generally been considered to be the principal mediator of IL-2 biologic activity (11, 12). Recent studies have indicated, however, that the IL-2R $\beta$ subunit itself is capable of mediating signal transduction (6) and have suggested that IL- $2 R \beta$ alone can mediate certain IL2 -induced biologic responses (13-15). The production of IL$2 \mathrm{R} \beta$ monoclonal antibodies which block IL- 2 binding to the IL-2R $\beta$ subunit of the IL- 2 receptor now make it possible to more directly assess the function and biologic role of IL-2R $\beta$ in IL-2-mediated cellular activation and cytokine production (16-21).

In this study we assessed the receptor-specific regulatory effects of IL-2 on cytokine production in unstimulated and activated $\mathrm{T}$ lymphocytes. We have particularly focused on the high affinity IL-2 receptor and on monomeric IL-2R $\beta$ and their possible differential mediation of IL-2-induced $T$ cell production of granulocyte-macrophage colony stimulating factor (GM-CSF) and IFN-gamma.

\section{Methods}

Antibodies and cytokines. OKT3 (CD3) mAb was purchased from Ortho Pharmaceuticals (Heidelberg, FRG), BMA30 (CD3) mAb from Behring (Marburg, FRG), and Leu 11 (CD16) mAb from Becton Dickinson (Heidelberg, FRG). My4 (CD14) and B1 (CD20) mAbs were obtained from Coulter Clone (Krefeld, FRG). The anti-IL-2 receptor mAbs anti-Tac (T. Waldmann, National Institutes of Health (NIH), Bethesda, MD) and 2A3 (Becton Dickinson) (CD25) react with the IL-2R $\alpha$ subunit of the IL-2 receptor. Both of these mAbs directly block IL-2 binding to IL-2R $\alpha$ and cause a consistent dose-dependent inhibition of $T$ cell proliferation induced by anti-CD3 mAb plus IL-2, with virtually complete abrogation at concentrations of $1 \mu \mathrm{g} / \mathrm{ml}$ (22). TU27 $\mathrm{mAb}$ is an $\mathrm{IgG}_{1}$ mAb that reacts with the p75 subunit of the IL-2 receptor (IL-2R $\beta$ ) and inhibits IL-2 binding to that subunit; it was 
generously provided by Dr. S. Taki (Anjinomoto Co., Kawasaki, Japan) (16). YTA-1 is a control $\mathrm{IgG}_{1} \mathrm{mAb}$ that does not inhibit IL-2 binding; YTA-1 was generously provided by Dr. Yodoi (Kyoto University, Japan) (21). Recombinant human IL-2 $\left(4.2 \times 10^{9} \mathrm{U} / \mathrm{g}\right.$ protein $)$ was generously provided by Cetus Corp. (Emeryville, $\mathrm{CA}$ and EuroCetus, Amsterdam, NL) and was $>98 \%$ pure by HPLC (23). Endotoxin content of the IL-2 stock was $2.5 \times 10^{-9} \mathrm{~g}$ per gram of IL-2.

Cell culture and cell separation procedures. PBMC were isolated from the blood of healthy donors using Ficoll-Hypaque gradient fractionation (24). All studies were approved by the Stanford Human Subjects Experimentation Committee and the Ethik-Kommission at Heinrich Heine University Medical Center. PBMC were depleted of monocytes by serial adherence to polystyrol plates $(<2 \%$ residual monocytes in the nonadherent fraction) to blunt endogenous IL-1 and subsequent IL-2 production. Abrogation of endogenous IL-2 production was monitored by IL-2 immunoassay (Amersham Corp., Arlington Heights, IL). Further $\mathrm{T}$ cell purification was achieved via magnetic cell sorting (MACS) (25): nonadherent PBMC suspensions were first incubated with a combination of primary $\mathrm{mAbs}$ including the monocyte mAb My 4 (CD14), a pan-B cell mAb B1 (CD20) and Leu 11 mAb (CD16) that recognizes a determinant on virtually all NK cells. Cell suspensions were next incubated with biotinylated goat anti-mouse IgG, streptavidin-fluoresceine, and biotinylated magnetic dextranferrit beads. Labeled and unlabeled cells were then separated using steel wool columns placed in a magnetic field of 0.6 Tesla. Two consecutive passages produced $95-99 \%$ pure $T$ cells as assessed by flow cytometry with $<1 \% \mathrm{CD} 16+\mathrm{NK}$ cells. In some experiments, $\mathrm{T}$ cells were subsequently fractionated into either CD4 or CD8 positive subsets using either direct or indirect solid-phase immunoabsorption, as previously described (24), or positive selection via magnetic cell sorting.

Before RNA extraction or supernatant harvest, T cells $\left(1-2 \times 10^{6} /\right.$ $\mathrm{ml}$ ) were cultured for 6-72 h in RPMI 1640 (Biochrom, Berlin, FRG) with $10 \%$ FCS or pooled human AB serum. Cultures were established in the presence or absence of recombinant human IL-2 $(1-100 \mathrm{U} / \mathrm{ml})$. In some experiments, $T$ cells were incubated with anti-CD3 $\mathrm{mAb}$ (OKT3) $(100 \mathrm{ng} / \mathrm{ml})$ for $20 \mathrm{~min}$ at $4^{\circ} \mathrm{C}$ before culture in the presence or absence of IL-2 (22). Cells were subsequently harvested for RNA extraction and supernatants assessed for cytokine activity. In some experiments, before culture with IL-2, T cells were first incubated with the IL-2R $\beta$ blocking mAb TU27 (10-50 $\mu \mathrm{g} / \mathrm{ml})$; under these conditions TU27 blocks binding of radioiodinated IL-2 to IL-2R $\beta$ as assessed by both chemical cross-linking and Scatchard plot analysis (16). In control experiments, we used cytofluorographic analysis to assess the ability of TU27 $\mathrm{mAb}(50 \mu \mathrm{g} / \mathrm{ml})$ to block biotinylated IL-2 $(100 \mathrm{U} / \mathrm{ml})$ binding to IL-2R $\beta$ on unstimulated $T$ cells. In three experiments, IL- 2 bound to $8.8 \pm 1.1 \%$ of unstimulated T cells; phycoerythrin-conjugated TU27 $\mathrm{mAb}$ bound to $10 \pm 1.6 \%$ of unstimulated T cells. Prior incubation with TU27 mAb suppressed IL-2 binding to $0.7 \pm 0.4 \%$, whereas isotype control $\mathrm{mAb}$ had no effect on IL-2 binding.

Because of the $\sim 40$-fold greater affinity of the high affinity IL-2 receptor for IL-2 than for anti-IL-2R $\alpha \mathrm{mAb}$, it is necessary to use concentrations of anti-IL-2R $\alpha$ mAb in marked excess to prevent IL-2 binding $(26,27)$. In experiments assessing the role of IL-2 binding to IL$2 \mathrm{R} \alpha$, T cells were cultured with $10-100 \mathrm{U} / \mathrm{ml} \mathrm{IL}-2(100 \mathrm{pM}$ to $1 \mathrm{nM})$ in the presence of anti-Tac mAb (6.7 nM to $2.0 \mu \mathrm{M})$; anti-Tac was thus used at concentrations up to 2000 -fold molar excess of IL-2. Under these conditions, IL-2 binds to $<2 \%$ of the available high affinity IL-2 receptors and also fails to bind to the isolated low affinity IL-2R $\alpha$ subunit $(26,27)$.

RNA extraction and analysis. Total cellular RNA was extracted with phenol in the presence of vanadyl ribonucleoside complexes $(28$, 29) or by a guanidinium thiocyanate-phenol-chloroform procedure (30). RNA samples were quantitated by spectrophotometric analysis. $10-15 \mu \mathrm{g}$ of isolated RNA were separated by $1.2 \%$ agarose-formaldehyde gel electrophoresis. Ribosomal RNA was visualized on the gel by ethidium bromide to assess RNA integrity and verify sample amounts. Next, alkaline transfer to Hybont $\mathrm{N}+$ nylon membranes (Amersham Buchler, Braunschweig, FRG) was performed. A PstI/NcoI GM-CSF
cDNA fragment (31) or a PstI/HindII interferon-gamma cDNA fragment (32) was inserted into the pSPT18 T7 transcription vector (Boehringer-Mannheim, Houston, TX) to generate anti-sense mRNA probes. The linearized plasmids were transcribed in the presence of ${ }^{32}$ P-UTP (NEN DuPont, Dreieich, FRG) using T7 polymerase (33). Filter prehybridization was carried out for $4 \mathrm{~h}$ at $58^{\circ} \mathrm{C}$ in $50 \%$ formamide, $2.5 \mathrm{mmol} /$ liter phosphate buffer (pH 6.5), $5 \times \mathrm{SSC}, 5 \times$ Denhardt's, $60 \mathrm{mg} / \mathrm{ml}$ salmon sperm DNA, $200 \mathrm{mg} / \mathrm{ml}$ yeast RNA, and $0.1 \%$ SDS. For hybridization, 0.1 vol of $50 \%$ dextran sulfate and labeled anti-sense mRNA were added and the filters were incubated for $20 \mathrm{~h}$ at $58^{\circ} \mathrm{C}$. Filters were washed twice with $0.2 \times \mathrm{SSC}$ at $60^{\circ} \mathrm{C}$ and then incubated for 15-40 min at room temperature in $2 \times$ SSC containing $50 \mathrm{ng} / \mathrm{ml} \mathrm{RNase} \mathrm{A.} \mathrm{After} \mathrm{washing} \mathrm{with} 0.1 \times \mathrm{SSC}$ and $0.1 \%$ SDS at $60^{\circ} \mathrm{C}$, filters were exposed to $x$ ray film $(3 \mathrm{M}, \mathrm{St}$ Paul, $\mathrm{MN})$ with intensifier screen at $-70^{\circ} \mathrm{C}$.

In some experiments, GM-CSF mRNA expression was visualized with an alternative procedure, an S1 nuclease protection assay. Before hybridization, parallel RNA aliquots were visualized on ethidium bromide-stained $1.2 \%$ agarose-formaldehyde gels to assess RNA integrity and to verify sample amounts. The 5 ' end-labeled NcoI linearized fragment of GM-CSF CDNA clone 3-8a was hybridized with $10 \mu \mathrm{g}$ samples of total RNA in $15 \mu \mathrm{l}$ containing $80 \%$ formamide, $1 \mathrm{mM}$ EDTA, and $50 \mathrm{mM}$ Pipes (pH 6.4) at $50^{\circ} \mathrm{C}(34)$. After $6 \mathrm{~h}$ of incubation, $150 \mu \mathrm{l}$ of cold S1 digestion buffer containing $200 \mathrm{U} / \mathrm{ml} \mathrm{S1}$ nuclease (BoehringerMannheim), $250 \mathrm{mM} \mathrm{NaCl}, 30 \mathrm{mM} \mathrm{NaAc}$, and $1 \mathrm{mM} \mathrm{ZnCl}$ was added to the hybridization mixture and incubated for $45 \mathrm{~min}$ at $37^{\circ} \mathrm{C}$. S1-resistant hybrids were precipitated by $2 \mathrm{vol}$ of ethanol, fractionated on a $5 \%$ polyacrylamide gel containing $7 \mathrm{M}$ urea, and subjected to autoradiography. Concurrent aliquots were hybridized with $\beta$-actin cDNA to help confirm that similar amounts of RNA were added to each lane.

Protein immunoassays. GM-CSF protein concentrations in T cellderived supernatants were assessed by ELISA using the Genzyme human GM-CSF ELISA kit (Genzyme Corp., Boston, MA). Sensitivity of the assay was $20 \mathrm{pg} / \mathrm{ml}$ and no cross-reactivity exists in the assay for IL-3, G-CSF, TNF $\alpha$, or interferon-gamma. Supernatant interferongamma concentrations were assessed by solid-phase radioimmunoassay (Centocor Inc., Malvern, PA). Recombinant interferon-gamma was used as standard and calibrated against human NIH standard (Gg23-901-530). The sensitivity of the assay is $\geq 0.5 \mathrm{U} / \mathrm{ml}$ of reference standard.

Cross-linking. Biochemical cross-linking was performed to better define $\mathrm{T}$ cell receptor IL-2-binding proteins. Resting cells and cells activated with immobilized CD3 mAb were cultured for 4-20 h in the absence of IL-2. T cells were then incubated with $75 \mathrm{pM}$ to $5 \mathrm{nM}$

${ }^{125}$ I-IL-2 for $1 \mathrm{~h}$ on ice. Cells were then treated with the chemical crosslinker disuccinimidyl suberate (DSS; Pierce Chemical Co., Rockford, IL) at a final concentration of $0.6 \mathrm{mM}$ for $30 \mathrm{~min}$ at room temperature $(7,35)$. The DSS-treated cells were lysed in PBS $1 \%$ Triton X-100 and lysates subsequently subjected to $7.5 \%$ SDS-PAGE and autoradiography.

Cytofluorographic analysis. Cell surface antigenic expression was assessed after antibody staining on a fluorescent activated cell sorter (FACS ${ }^{\oplus}$ Star Plus; Becton Dickinson) as previously described (24).

\section{Results}

GM-CSF and interferon-gamma protein secretion. Unstimulated and CD3-activated $T$ cells were cultured in the presence or absence of IL-2 to assess the effect of IL-2 on T cell GM-CSF and IFN-gamma protein secretion. After 3-5 d of culture $75 \pm 12 \%$ of CD3-triggered $\mathrm{T}$ cells cultured in the presence of IL-2 expressed the IL-2R $\alpha$ receptor by cytofluorographic analysis, while only $4 \pm 2 \%$ of unstimulated T cells cultured with IL-2 alone were IL-2R $\alpha$ receptor positive. Supernatants were harvested at day 3 of culture and lymphokine content was assessed by immunoassay (Fig. 1). Resting $\mathrm{T}$ cells were stimulated to 

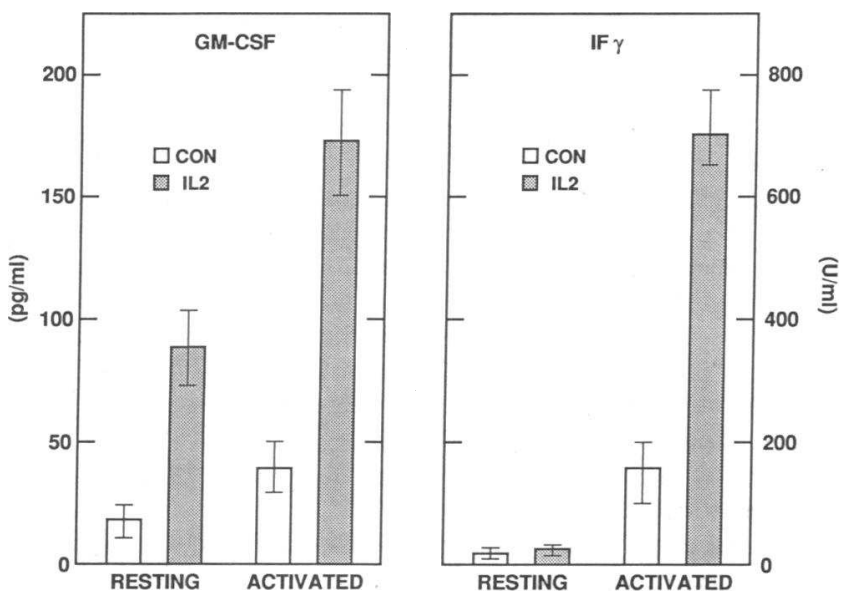

Figure 1. IL-2 $\left(10^{2} \mathrm{U} / \mathrm{ml}\right)$-induced release of GM-CSF and IFNgamma from resting and activated peripheral blood T cells. Supernatants harvested after $3 \mathrm{~d}$ of incubation. CON denotes either resting $\mathrm{T}$ cells cultured in the absence of IL-2 or activated T cells stimulated with anti-CD3 mAb and cultured in the absence of IL-2. Results expressed as mean \pm SEM from six separate experiments.

release GM-CSF in response to IL-2, resulting in a fivefold increase in GM-CSF secretion at $10^{2} \mathrm{U} / \mathrm{ml} \mathrm{IL-2} \mathrm{compared} \mathrm{with}$ control. In contrast, IL-2 stimulation of resting $\mathrm{T}$ cells resulted in minimal release of interferon-gamma. GM-CSF and interferon-gamma release from CD3-activated $T$ cells increased four- to fivefold in the presence of $10^{2} \mathrm{U} / \mathrm{ml}$ IL-2 relative to CD3-activated $T$ cells cultured in the absence of IL-2.

Recent studies suggest that the IL-2R $\beta$ subunit is predominantly expressed on CD8 + rather than CD4+ T cells (18). We examined unstimulated immunopurified CD4+ and CD8+ $\mathrm{T}$ cells (containing $<1 \%$ CD16+ NK cells) for IL-2R $\beta$ expression by cytofluorographic analysis and subsequently assessed both $T$ cell subsets for GM-CSF and IFN-gamma release after IL-2 stimulation. In five separate experiments, IL-2R $\beta$ was expressed on $11.4 \pm 2.6 \%$ of CD8 $+\mathrm{T}$ cells and on $6.8 \pm 1.5 \%$ of CD4+ T cells. Unstimulated CD8 $+T$ cells $(7 \pm 5 \mathrm{pg} / \mathrm{ml})$ were stimulated to release GM-CSF after $3 \mathrm{~d}$ of culture with $10^{2}$ $\mathrm{U} / \mathrm{ml}$ IL-2 $(64 \pm 10 \mathrm{pg} / \mathrm{ml})$. IL-2 similarly stimulated release of GM-CSF from unstimulated CD4+ T cells $(10 \pm 4$ to $53 \pm 9 \mathrm{pg} /$ $\mathrm{ml})$. Neither unstimulated CD4+ nor CD8 $+\mathrm{T}$ cells released appreciable amounts of IFN-gamma after IL-2 stimulation (7$19 \mathrm{U} / \mathrm{ml}$ ); in contrast, marked IFN-gamma release was observed in both activated CD4+ and CD8+ T cells (110-325 $\mathrm{U} / \mathrm{ml}$ ) after IL-2 stimulation.

Lymphokine mRNA expression. IL-2 induction of GM$\mathrm{CSF}$ and interferon-gamma mRNA expression was next assessed in both unstimulated and activated T cells. CD3-activated and resting $T$ cells were cultured in the presence or absence of IL-2 for 6-20 h. RNA was subsequently extracted and assessed for lymphokine mRNA expression by Northern analysis and S1 nuclease protection assay (Fig. 2). IL-2 markedly augmented expression of GM-CSF mRNA in unstimulated T cells. Activation with $\mathrm{CD} 3 \mathrm{mAb}$ alone resulted in a modest increase in T cell GM-CSF mRNA expression which was markedly augmented in the presence of IL-2 (Fig. $2 \mathrm{~A}$ ). In contrast, IL-2 failed to augment interferon-gamma mRNA expression in unstimulated $\mathrm{T}$ cells but did markedly augment interferongamma mRNA in CD3-activated T cells (Fig. 2 B).
A
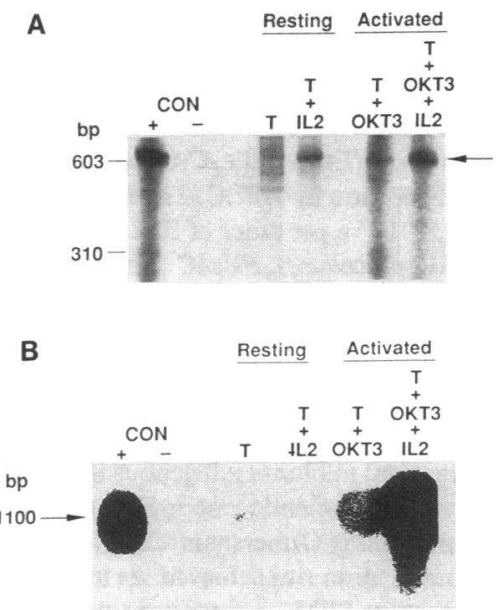

Figure 2. (A) IL-2-induced augmentation of GM-CSF mRNA expression in resting and activated $T$ cells. Assessment by $S 1$ nuclease protection assay. Resting cells $(T)$ were assessed in the presence and absence of IL-2 $\left(10^{2}\right.$ $\mathrm{U} / \mathrm{ml}$ ). Activated $\mathrm{T}$ cells were harvested after incubation with anti-CD3 $\mathrm{mAb}(O K T 3)$ or after incubation with antiCD3 mAb plus IL-2 $(O K T 3+I L 2)$. Cells were cultured for $8 \mathrm{~h}$ before harvesting for RNA extraction. The negative control $(-C O N)$ consists of labeled cDNA plus carrier RNA without $T$ cell RNA. The positive control $(+C O N)$ comprised cDNA plus RNA from an HTLV-II-infected T cell line (Mo). The position of complexed GM-CSF mRNA on the gel is indicated by an arrow $(600 \mathrm{bp})$. (B) IL-2-induced augmentation of IFN-gamma mRNA expression in resting and activated $T$ cells. Assessment by Northern analysis. Negative control $(-C O N)$ consists of labeled cDNA plus carrier RNA without T RNA. The positive control $(+C O N)$ consists of cDNA plus RNA from a HTLV-II-infected $\mathrm{T}$ cell line (Mo). Resting $\mathrm{T}$ cells were assessed in the presence or absence of IL-2 $\left(10^{2} \mathrm{U} / \mathrm{ml}\right)$. Activated T cells were harvested after incubation with anti-CD3 mAb $(O K T 3)$ or after incubation with anti-CD3 mAb plus IL-2 $(O K T 3+I L 2)$. Cells were cultured for $14 \mathrm{~h}$ before RNA extraction.

IL-2-ligand receptor binding. We next assessed possible IL2 receptor moieties involved in IL-2 binding to either unstimulated or activated $\mathrm{T}$ cells using chemical cross-linking experiments. Resting and CD3-activated T cells were cultured for $4 \mathrm{~h}$ in the absence of exogenous IL-2. T cells were harvested and exposed to $5 \mathrm{nM}^{125} \mathrm{I}$-labeled IL-2 before chemical ligand receptor-cross-linking. Cell lysates were analyzed by SDS-PAGE and autoradiography. Fig. 3 demonstrates IL-2 binding to 70-75 (i.e., IL-2R $\beta$ ) and $55 \mathrm{kD}$ (i.e., IL-2R $\alpha$ ) receptor molecules in

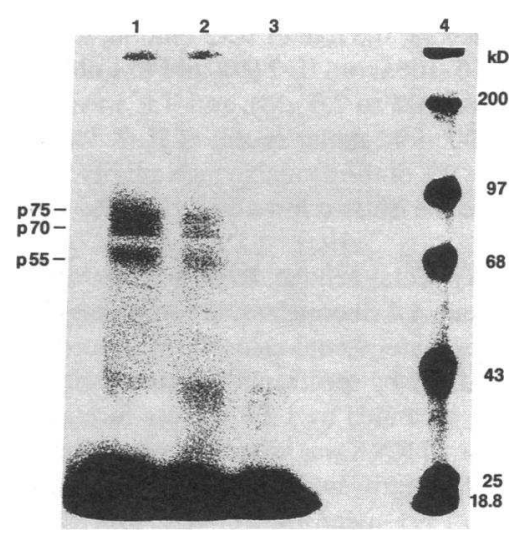

Figure 3. SDS-PAGE of cross-linked ${ }^{125}$ I-IL-2 to $T$ cell-binding proteins. (Lane 1) Membrane lysate of resting $T$ cells; (lane 2) lysate of $T$ cells incubated for 4 $\mathrm{h}$ with anti-CD3 $\mathrm{mAb}$; (lane 3) binding of ${ }^{125} \mathrm{I}$ IL-2 to resting T cells in the presence of 100 fold excess of unlabeled IL-2; (lane 4) ${ }^{14} \mathrm{C}$-labeled molecular weight markers. On the ordinate, $p 70$ plus $p 75$ together refer to IL-2R $\beta$ and $p 55$ refers to IL$2 \mathrm{R} \alpha$. 
unstimulated as well as in activated T cells. After $20 \mathrm{~h}$ of culture, the $55-\mathrm{kD}$ binding protein was markedly upregulated in CD3-activated T cells and IL-2 binding was still demonstrable to both 55- and 70-75-kD receptor moieties (data not shown). In control experiments, binding of ${ }^{125} \mathrm{I}-\mathrm{IL}-2$ to its receptors was eliminated by competition with 100 -fold excess of unlabeled IL-2 (Fig. 3, lane 3). Binding to both 55- and 70-75-kD proteins was still demonstrable in activated $T$ cells (and was blocked with anti-Tac mAb) when only $100 \mathrm{pM}$ of ${ }^{125} \mathrm{I}$-labeled IL-2 was used for cross-linking; binding, however, was not demonstrable in resting $\mathrm{T}$ cells after attempted cross-linking with 100 pM IL-2 (data not shown).

Blockade of the $I L-2 R \alpha$ and $I L-2 R \beta$ receptors. We next used receptor-specific blocking $\mathrm{mAbs}$ to assess the relative roles of the IL-2R $\alpha$ and IL-2R $\beta$ subunits in mediating IL-2-induced $T$ cell lymphokine production. Unstimulated and CD3-activated $T$ cells were incubated with the IL-2R $\beta$ blocking $\mathrm{mAb}$ TU27 or the IL-2R $\alpha$ blocking mAb anti-Tac before culture with IL-2. GM-CSF and IFN-gamma protein secretion were assessed in supernatants harvested after 3-5 d of culture. In unstimulated as well as in CD3-activated T cells, TU27 mAb decreased GM-CSF release in a dose-dependent manner (Fig. 4 A). A control mAb (YTA-1), which does not inhibit IL-2 binding to the IL-2R, had no effect on GM-CSF release (data not shown). Blockade of the IL-2R $\alpha$ receptor subunit with anti-Tac mAb (using anti-Tac concentrations up to 2,000-fold molar excess of IL-2) failed to diminish IL-2-induced GM-CSF protein release in either resting or activated $\mathrm{T}$ cells (Fig. $4 \mathrm{~B}$ ). In contrast, IL-2R $\alpha$ receptor blockade markedly decreased IL-2induced release of interferon-gamma from activated $\mathrm{T}$ cells $(90 \pm 8 \%)$, while IL-2R $\beta$ blockade decreased IFN-gamma release by only $8 \pm 7 \%$ (Fig. $4 \mathrm{~B}$ ). The combination of anti-Tac plus TU27 mAbs also markedly reduced release of both GMCSF and IFN-gamma from activated T cells (data not shown).

IL-2 stimulated resting $T$ cells to release GM-CSF, but not IFN-gamma, in a dose-dependent manner (Fig. 5); marked stimulation was seen in the range of $300 \mathrm{pM}$ to $1 \mathrm{nM}(\sim 30$ $100 \mathrm{U} / \mathrm{ml})$. These concentrations are consistent with those concentrations needed to bind the isolated IL-2R $\beta$ subunit of the IL-2 receptor (26). Blockade with anti-Tac mAb did not alter the configuration of the IL-2 binding curve for GM-CSF release from unstimulated $T$ cells. Maximal release of both GM-CSF and IFN-gamma from activated T cells occurred with $\sim 100 \mathrm{pM}(10 \mathrm{U} / \mathrm{ml}) \mathrm{IL}-2$ (Fig. 5); high affinity IL-2 receptors are nearly saturated at this concentration, whereas low affinity (IL-2R $\alpha$ ) receptors are minimally occupied at 100 pM (26). Blockade with anti-Tac markedly suppressed IFN-gamma release from activated $\mathrm{T}$ cells. Although anti-Tac blockade had little demonstrable effect on GM-CSF release at high IL-2 concentrations (e.g., $1 \mathrm{nM}$ ), anti-Tac did markedly shift the GMCSF IL-2 dose-response curve to the right.

We next assessed to what extent blockade of either the IL$2 \mathrm{R} \alpha$ or IL-2R $\beta$ subunit modulated T cell lymphokine mRNA expression. Unstimulated cells and cells triggered with antiCD3 mAb were incubated with $10^{2} \mathrm{U} / \mathrm{ml} \mathrm{IL-2}$ for $6-20 \mathrm{~h}$ before RNA extraction and analysis by Northern blotting. Blockade of the IL-2R $\beta$ subunit with TU27 mAb before CD3 triggering resulted in a clear reduction in IL-2-dependent GM-CSF mRNA expression (Fig. $6 A$, lane 4 ). Similarly, IL-2R $\beta$ blockade in unstimulated $\mathrm{T}$ cells also markedly diminished IL-2-dependent GM-CSF mRNA expression (data not shown). In con-
A.
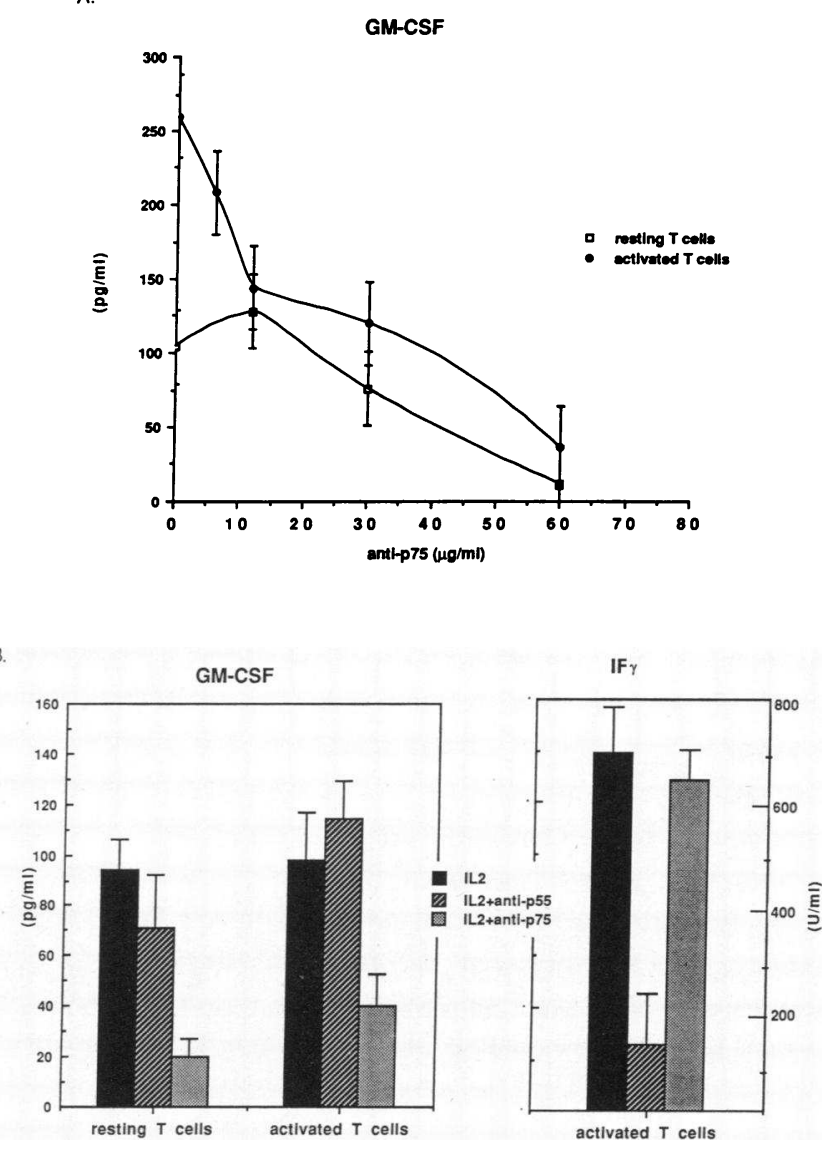

Figure 4. $(A)$ Effect of IL-2R $\beta$ ( $p 75)$ blockade with TU27 mAb on IL-2 $\left(10^{2} \mathrm{U} / \mathrm{ml}\right)$-induced release of GM-CSF from resting and CD3activated $T$ cells. Results expressed as mean \pm SEM from four separate experiments. ( $B$ ) Effect of IL-2R $\alpha(p 55)$ and IL-2R $\beta(p 75)$ blockade on GM-CSF and IFN-gamma (IF $\gamma$ ) release from either resting or activated $T$ cells. IL-2 denotes $T$ cells cultured with $10^{2} \mathrm{U} / \mathrm{ml}$ IL-2 (resting cells) or T cells cultured with $10^{2} \mathrm{U} / \mathrm{ml} \mathrm{IL-2}$ plus anti-CD3 $\mathrm{mAb}$ (activated cells); anti-p55 denotes $\mathrm{T}$ cells preincubated with anti-Tac mAb before culture with IL-2; anti-p75 denotes T cells preincubated with TU27 before culture with IL-2. Results expressed as mean \pm SEM from three separate experiments.

trast, IL-2R $\beta$ blockade had little effect on IL-2-induced interferon-gamma mRNA expression in $\mathrm{T}$ cells triggered with the anti-CD3 mAb (Fig. $6 \mathrm{~B}$, lane 4). Although blockade of the IL-2R $\alpha$ subunit with anti-Tac $m A b$ had little effect on IL-2-dependent GM-CSF mRNA expression in CD3-triggered $\mathrm{T}$ cells (Fig. $6 \mathrm{~A}$, lane 3 ) or in unstimulated $\mathrm{T}$ cells, anti-Tac $\mathrm{mAb}$ markedly diminished interferon-gamma mRNA expression (Fig. $6 B$, lane 3).

\section{Discussion}

Our results demonstrate that $(a)$ IL-2 is capable of binding to 55- and 70-75-kD receptor moieties in both unstimulated and activated T cells; (b) IL2 induces GM-CSF mRNA expression and protein release in both unstimulated and activated $\mathrm{T}$ cells, whereas IL-2-induced IFN-gamma protein release and mRNA expression is confined to activated T cells; (c) IL-2-induced 

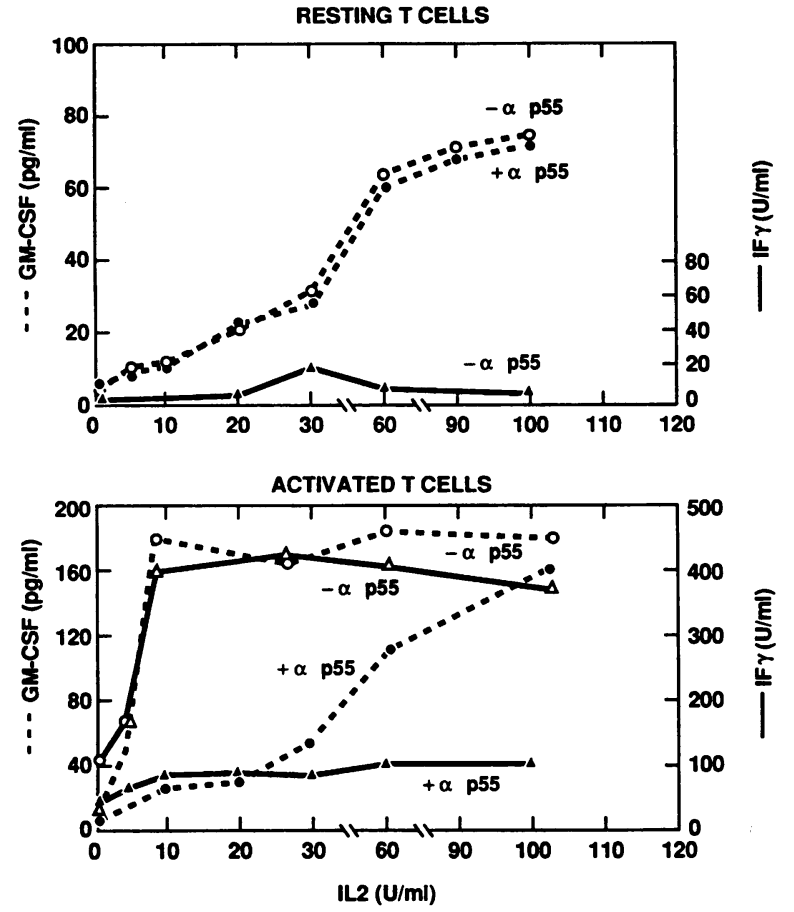

Figure 5. IL-2 dose-response curves assessing release of GM-CSF and IFN-gamma from resting and activated $T$ cells. $T$ cell supernatants were harvested after $3 \mathrm{~d}$ of culture before immunoassay. $-\alpha p 55$ and $+\alpha p 55$ denotes $\mathrm{T}$ cells cultured in the absence or the presence of anti-Tac mAb, respectively.

GM-CSF production in unstimulated $\mathrm{T}$ cells is directly mediated via the IL-2R $\beta$ receptor; IL-2R $\beta$ alone is also capable of mediating GM-CSF production in populations of activated $T$ cells, whereas the high affinity IL-2 receptor predominantly mediates $T$ cell IFN-gamma production. These data suggest that unstimulated and activated $T$ cells which express distinct IL-2 receptor moieties can differentially modulate $T$ cell lymphokine production.

Almost all cellular responses to IL-2, including T and B cell proliferation and differentiation as well as lymphokine secretion, have been attributed to the interaction of IL-2 with high affinity receptors containing the IL-2R $\alpha$ protein $(11,12)$. However, a number of recent observations have suggested that IL-2 is capable of inducing intracellular signals in cells expressing the IL-2R $\beta$ protein in the absence of the high affinity Tac-containing receptor. Human NK cells are rapidly activated by IL2 , causing augmented cytotoxic activity and proliferation (13). Although resting NK cells do not express IL-2R $\alpha$, cross-linking experiments have demonstrated the presence of IL-2R $\beta$ on NK cell membranes (36). Recent experiments using the TU27 $\mathrm{mAb}$ have indicated that IL-2R $\beta$ is predominantly responsible for IL-2 activation of NK cells and is the molecule that mediates IL-2 induction of NK cell GM-CSF production $(37,38)$. IL-2 can also induce B cell lines to secrete immunoglobulin in the absence of Tac surface protein; the binding site responsible for this effect shares many characteristics with the IL- $2 R \boldsymbol{\beta}$ protein $(14,36)$. Several studies indicate that IL-2R $\beta$ alone is capable of signal transduction: for example, IL-2 bound to IL-2R $\beta$ is internalized with the same kinetics as that observed for the high affinity form of the receptor (4).

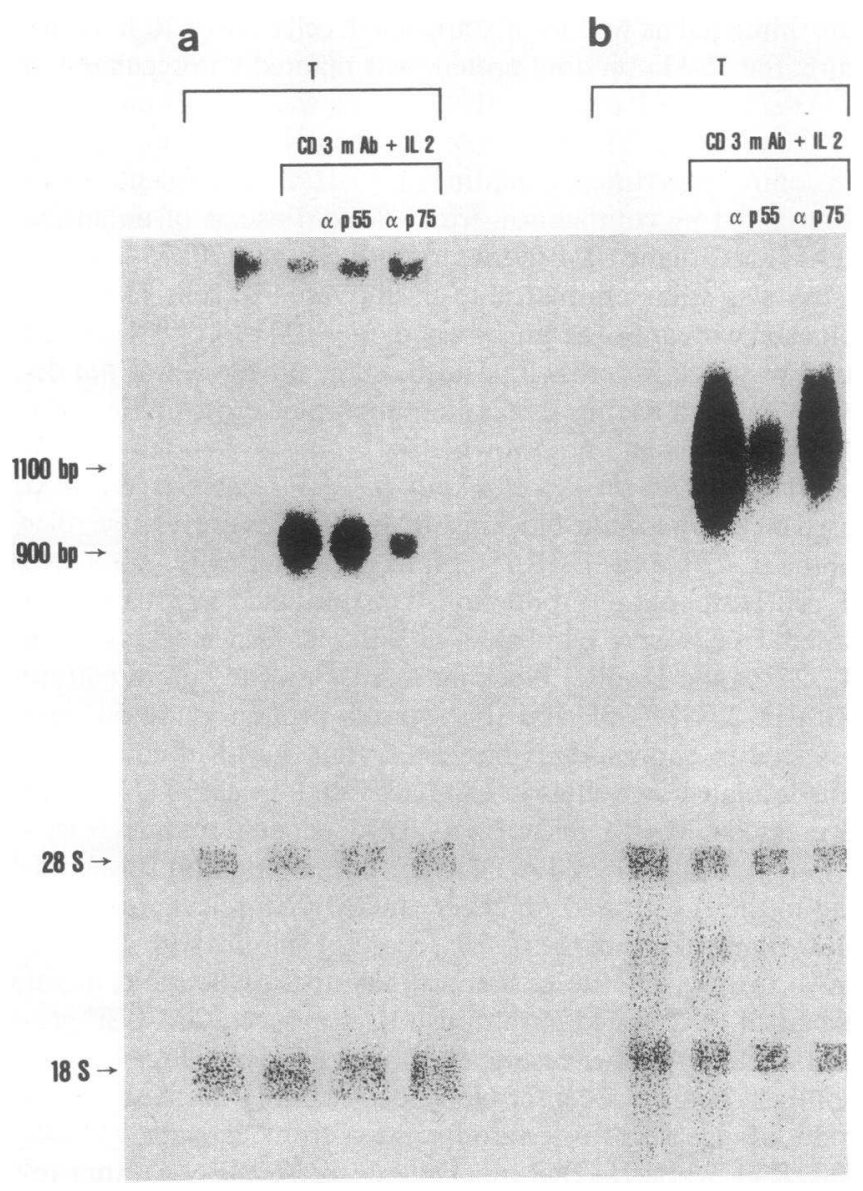

Figure 6. $(A)$ Effect of IL-2R $\alpha(p 55)$ and IL-2R $\beta$ ( $p 75)$ blockade on IL-2-induced augmentation of GM-CSF mRNA from activated T cells. Assessment by Northern analysis. (Lane 1 ) Resting $T$ cells cultured in the absence of IL-2; (lane 2) CD3-activated T cells cultured in the presence of $10^{2} \mathrm{U} / \mathrm{ml} \mathrm{IL-2;}$ (lane 3 ) T cells preincubated with anti-Tac mAb before activation and culture with CD3 mAb plus $10^{2}$ $\mathrm{U} / \mathrm{ml} \mathrm{IL-2;}$ (lane 4) $\mathrm{T}$ cells preincubated with TU27 mAb before activation and culture with CD3 $\mathrm{mAb}$ plus $10^{2} \mathrm{U} / \mathrm{ml} \mathrm{IL}-2$. Cells were cultured for $8 \mathrm{~h}$ before RNA extraction. Ribosomal control bands are indicated (18S and $28 S)$ for each lane. (B) Effect of IL-2R $\alpha(p 55)$ and IL-2R $\beta$ ( $p 75)$ blockade on IL-2-induced augmentation of IFNgamma mRNA from activated T cells. Assessment by Northern analysis. (Lane 1) Resting T cells cultured in the absence of IL-2; (lane 2) CD3-activated T cells cultured with $10^{2} \mathrm{U} / \mathrm{ml} \mathrm{IL-2;} \mathrm{(lane} \mathrm{3)} \mathrm{T} \mathrm{cells}$ preincubated with anti-Tac $\mathrm{mAb}$ before activation and culture with CD3 mAb plus $10^{2} \mathrm{U} / \mathrm{ml}$ IL-2; (lane 4) T cells preincubated with TU27 mAb before activation and culture with CD3 mAb plus $10^{2}$ $\mathrm{U} / \mathrm{ml}$ IL-2. Cells were cultured for $14 \mathrm{~h}$ before RNA extraction. Ribosomal RNA control bands ( $18 S$ and $28 S$ ) are indicated for each lane.

Our cross-linking data indicate that high $(5 \mathrm{nM})$ concentrations of IL-2 are capable of binding to both 55- and 70-75-kD receptors on the surface of unstimulated T cells; low (100 pM) concentrations of IL-2 also bound to both subunits on activated $T$ cells (in the absence but not in the presence of anti-Tac) but did not bind to unstimulated $\mathrm{T}$ cells. Although our crosslinking data in unstimulated cells could represent binding of IL-2 to small numbers of cells expressing high affinity receptors, the data are more consistent with the precipitation of individual receptor proteins that exist either unassembled on the 
same cell or that are independently expressed on separate resting $\mathrm{T}$ cell populations. Ohashi et al. have recently suggested that IL-2R $\alpha$ is expressed on $8 \%$ of resting CD4+ T cells but is not detectable on resting CD8 $+\mathrm{T}$ cells; they observed IL-2R $\beta$ expression on $6.7 \%$ of resting CD8+ $T$ cells and negligible IL$2 \mathrm{R} \beta$ expression on $\mathrm{CD} 4+$ cells although 2 of 10 normal donors did demonstrate some IL-2R $\beta$ expression on CD4+ $T$ cells (18). Using two-color cytofluorographic analysis, we observed IL-2R $\beta$ expression on $\sim 11 \%$ of unstimulated CD8 $+\mathrm{T}$ cells and on $6.8 \%$ of unstimulated CD4 $+\mathrm{T}$ cells. These results are consistent with the demonstration by cross-linking of IL-2R $\beta$ on both CD4+ and CD8 + T cells (39). In accord with Ohashi's data, we have also observed IL-2R $\alpha$ on small numbers of unstimulated CD4+ T cells; however, using labeled TU27 and anti-Tac mAbs we have not detected resting $T$ cells that simultaneously express both IL-2R $\alpha$ and IL-2R $\beta$. These results suggest that IL-2R $\alpha$ and IL-2R $\beta$ may be independently expressed on separate $T$ cell subpopulations, possibly on varying functional subsets within either CD4+ or CD8+ subpopulations (40).

Little is known with regard to possible biologic roles subserved by the IL-2R $\beta$ protein on resting T cells. Some studies have suggested a role for IL-2R $\beta$ in direct activation of resting $T$ cells by relatively high IL-2 concentrations (15). Binding of IL-2 to IL-2R $\beta$ also appears sufficient to activate $\mathrm{Na}+/ \mathrm{H}+\mathrm{ex}-$ change and to induce c-myc and c-myb expression $(41,42)$. The IL- $2 \mathrm{R} \beta$ protein has also recently been implicated as the molecule most directly responsible for IL-2 induction of cytotoxic activity in resting peripheral blood CD8 $+\mathrm{T}$ cells (17). Our results demonstrate that IL-2R $\beta$ blocking mAb markedly suppresses IL-2-induced production of GM-CSF in unstimulated $\mathrm{T}$ cells. GM-CSF production could be mediated by IL$2 \mathrm{R} \beta$ in the context of the heterodimeric high affinity receptor either induced on resting T cells by IL-2 or possibly expressed on a small number of activated cells otherwise contained in our freshly isolated $\mathrm{T}$. cell population. However, several pieces of evidence favor the alternative hypothesis that GM-CSF production in unstimulated $\mathrm{T}$ cells is mediated predominantly by monomeric IL-2R $\beta$. First, the IL- 2 concentrations ( $300 \mathrm{pM}$ to $1 \mathrm{nM}$ ), which optimally stimulate GM-CSF release from unstimulated $T$ cells, are consistent with those concentrations needed to bind isolated IL-2R $\beta$; high affinity IL-2 receptors are nearly saturated at $100 \mathrm{pM}(26)$. Second, although high molar concentrations of anti-Tac mAb markedly suppressed IFNgamma production from activated $T$ cells, anti-Tac had no effect on IL-2-induced expression of GM-CSF mRNA or on IL-2-induced release of GM-CSF from unstimulated T cells. Third, anti-Tac also failed to alter the apparent affinity of IL-2 for its receptor on unstimulated T cells (Fig. 5). Fourth, IL-2R $\alpha$ blockade does not appear to inhibit IL-2 binding to IL-2R $\beta$ (16). Finally, our own as well as published cytofluorographic data (18) suggest that IL-2R $\alpha$ and IL-2R $\beta$ are independently expressed on separate $T$ cell subpopulations. Taken together, these data strongly suggest that monomeric IL-2R $\beta$ mediates GM-CSF production in unstimulated T cells. As with other demonstrated activities mediated by IL- $2 R \beta$, the concentrations of IL-2 required for GM-CSF production in unstimulated $T$ cells are quite high; although the concentrations of IL- 2 produced locally and that may be available for paracrine activity remain speculative, the in vivo significance of IL-2 binding to IL- $2 R \beta$ in the absence of IL-2R $\alpha$ expression remains to be determined.
IL-2 induces both GM-CSF and IFN-gamma production from populations of activated $\mathrm{T}$ cells. Activated $\mathrm{T}$ cells express the high affinity heterodimer $\mathrm{IL}-2$ receptor; most activated $\mathrm{T}$ cells in our studies demonstrated marked upregulation of Tac antigen 3-5 d after antigen receptor triggering with CD3 $\mathrm{mAb}$, an observation fully compatible with enhanced expression of the high affinity receptor. The amount of IL-2 required for optimal release of both GM-CSF and IFN-gamma from activated cells in the absence of blocking $\mathrm{mAb}$ was $\sim 100 \mathrm{pM}$; this IL-2 concentration will nearly saturate the high affinity receptor. Indeed, anti-Tac mAb markedly suppressed IFN-gamma mRNA expression and protein release from activated $T$ cells cultured with IL-2, although blocking IL-2R $\beta$ with high concentrations of TU27 mAb had only a marginal effect on IFNgamma production. TU27 mAb probably does not fully block IL-2 binding to the high affinity receptor, perhaps because the affinity of IL-2 for its high affinity receptor $\left(K_{\mathrm{d}} \approx 5-10 \mathrm{pM}\right)$ is much greater than is the affinity of TU27 $\left(K_{d} \approx 2.1 \mathrm{nM}\right)(16)$. Taken together, these data indicate that the high affinity receptor most probably mediates IL-2-induced production of IFNgamma from activated $\mathrm{T}$ cells. A less likely alternative is that IFN-gamma production is mediated in part by IL-2 binding to monomeric IL-2R $\alpha$, a low affinity IL-2 receptor that may in some situations be capable of signal transduction (43).

Maximal release of GM-CSF from activated T cells occurs with only 100 pM IL-2, suggesting that the high affinity receptor on activated cells is capable of mediating GM-CSF production. In contrast to the effect on IFN-gamma release, IL-2R $\alpha$ blockade did not totally suppress GM-CSF release but rather altered the apparent affinity of the receptor mediating that release. In the presence of IL-2R $\alpha$ blockade, $300 \mathrm{pM}$ to $1 \mathrm{nM}$ IL-2 is required for optimal GM-CSF release from activated T cells; these concentrations are consistent with mediation by an intermediate affinity receptor. Prior studies have indicated that anti-IL-2R $\alpha$ mAb does not block IL-2 binding to IL-2R $\beta$ (16) and that both IL-2R $\alpha$ and IL-2R $\beta$ interact with separate IL-2 epitopes $(4,44)$. These results in toto suggest that IL-2R $\beta$ is capable of mediating GM-CSF release, but not IFN-gamma release, from activated T cells, even in the presence of IL-2R $\alpha$ blockade. Either IL-2R $\beta$ in the context of the IL-2R $\alpha / \mathrm{IL}-2 \mathrm{R} \beta$ heterodimer on activated cells, or alternatively, monomeric IL$2 \mathrm{R} \beta$ on residual resting cells contained in the largely activated $T$ cell population, may mediate GM-CSF production in the setting of IL-2R $\alpha$ blockade. Blockade of IL-2R $\alpha$ is capable of enhancing IL-2R $\beta$-like expression on cells bearing high affinity IL-2 receptors; addition of anti-Tac to activated YT cells has been reported to cause a loss of the high affinity component of binding and a reappearance of the intermediate affinity IL-2R $\beta$ binding site, suggesting possible disassembly of the high affinity complex (44). Blockade of IL-2R $\beta$ with TU27 markedly suppresses IL-2-induced production of GM-CSF but not IFNgamma in activated T cells; these results suggest that IL- 2 binding to an epitope on IL-2R $\beta$, recognized by TU27 but possibly distinct from the epitope contributing to the high affinity receptor, is required for IL-2 induction of T cell GM-CSF production.

It is possible that differences in cytokine production in our experiments could be explained by different requirements for percent receptor occupancy for maximal effects. However, there are at least two pieces of data that do not support this hypothesis: (a) differences in requirements for percent receptor 
occupancy would be likely to yield different dose-response curves for GM-CSF versus IFN-gamma in the absence of blocking $\mathrm{mAbs}$. However, Fig. $5 \mathrm{~B}$ does not indicate any appreciable differences in the shape of these two curves. (b) In resting $T$ cells, even large amounts of IL-2 fail to produce much release of IFN-gamma (for example, see Fig. $5 \mathrm{~A}$ ).

Our studies suggest an independent role for the IL-2R $\beta$ protein in mediating GM-CSF production from $T$ cells. They also suggest that distinct IL-2 receptor proteins may mediate release of separate lymphokines and perhaps play an important role in the regulation of cytokine production. Signal transduction initiated by IL- $2 R \beta$ binding may differ in some substantial way from that initiated by binding to the IL-2R $\alpha / \mathrm{IL}-2 \mathrm{R} \beta$ receptor complex. Alternatively, it is possible that the small subset of unstimulated $T$ cells bearing the IL- $2 R \beta$ subunit may differ in some qualitative way from the majority of activated $\mathrm{T}$ cells bearing the high affinity heterodimer. There are many differences between resting and activated $T$ cells and it may be that differences in cytokine production relate in part to the activation state of the cell rather than solely to differential IL-2 receptor expression. It may be possible to differentially regulate responses to IL-2 by selectively modulating the interaction of IL-2 with its component receptor proteins which appear to be heterogeneously expressed on varying $T$ lymphocyte subpopulations.

\section{Acknowledgments}

We gratefully acknowledge the advice of Dr. Urte Kyas and Dr. Karl Welte as well as the expert technical assistance of Kerstin Bachtenkirch, Dorothy Humbert, and Barbara Buttlies. We also wish to thank Drs. F. Lee, D. Krummwieh, and P. Habermann for provision of GMCSF cDNAs and Drs. T. Waldmann, K. Sugamura, and S. Taki for providing Tac-1 and TU27 mAbs.

This work was supported by grants from the National Heart, Lung, and Blood Institute (R01 HL-35774), the Deutsche Forschungsgemeinschaft (Bu 578/2-1), the Deutsche Krebshilfe (W20/87 Bu 1), and the Elterninitiative Kinderkrebsklinik. Dr. Levitt is the recipient of a Research Career Development Award (K04 HL-02213-01) from the National Institutes of Health.

\section{References}

1. Smith, K. 1988. Interleukin-2: inception, impact, and implications. Science (Wash. DC). 240:1169-1176.

2. Trinchieri, G., M. Matsumoto-Kobayashi, S. Clark, J. Seehra, L. London, and B. Perussia. 1984. Response of resting human peripheral blood natural killer cells to interleukin 2. J. Exp. Med. 160:1147-1169.

3. Greene, W., W. Leonard, and J. Depper. 1986. Growth of human T lymphocytes: an analysis of interleukin 2 and its cellular receptor. Prog. Hematol. 14:283-301.

4. Greene, W. 1987. The human interleukin 2 receptor: a molecular and biochemical analysis of structure and function. Clin. Res. 35:439-450.

5. Waldmann, T. 1986. The structure, function and expression of interleukin 2 receptors on normal and malignant lymphocytes. Science (Wash. DC). 232:727-732.

6. Robb, R., and W. Greene. 1987. Internalization of interleukin 2 is mediated by the $\beta$ chain of the high affinity interleukin 2 receptor. J. Exp. Med. 165:1201-1206.

7. Sharon, M., R. Klausner, B. Cullen, R. Chizzonite, and W. Leonard. 1986. Novel interleukin 2 receptor subunit detected by crosslinking under high affinity conditions. Science (Wash. DC). 234:859-863.

8. Teshigawara, K., H.-M. Wang, K. Kato, K. Smith. 1987. Interleukin 2 high affinity receptor expression requires two distinct binding proteins. J. Exp. Med. 165:223-238.

9. Welte, K., M. Andreeff, E. Platzer, K. Holloway, B. Rubin, M. Moore, and
R. Mertelsmann. 1984. Interleukin 2 regulates expression of TAC antigen on peripheral blood T lymphocytes. J. Exp. Med. 160:1390-1403.

10. Smith, K., and D. Cantrell. 1985. Interleukin 2 regulates its own receptors. Proc. Natl. Acad. Sci. USA. 82:864-868.

11. Lowenthal, J., and W. Greene. 1987. Contrasting interleukin 2 binding properties of the $\alpha(\mathrm{p} 55)$ and $\beta$ (p70) protein subunits of the human high affinity interleukin 2 receptor. J. Exp. Med. 166:1156-1161.

12. Wang, H.-M., and K. Smith. 1987. The interleukin 2 receptor. Functional consequences of its bimolecular structure. J. Exp. Med. 166:1055-1069.

13. Ortaldo, J., A. Mason, J. Gerard, L. Henderson, W. Farrar, R. Hopkins, R. Herberman, and H. Rabin. 1984. Effects of natural and recombinant IL-2 on regulation of IF-gamma production and natural killer activity: lack of involvement of the Tac antigen for these immunoregulatory effects. J. Immunol. 133:779-783.

14. Ralph, P., G. Jeong, K. Welte, R. Mertelsmann, H. Rabin, L. Henderson, L. Souza, T. Boone, and R. Robb. 1984. Stimulation of immunoglobulin secretion in human B lymphocytes as a direct effect of high concentrations of IL-2. $J$. Immunol. 133:2442-2445.

15. Le Thi, B.-T., M. Dukovich, N. Peffer, A. Fauci, J. Kehrl, and W. Greene. 1987. Direct activation of human resting T cells by IL-2: the role of an IL-2 receptor distinct from the Tac protein. J. Immunol. 139:1550-1556.

16. Takeshita, T., Y. Goto, K. Tada, K. Nagata, H. Asao, and K. Sugarmura. 1989. Monoclonal antibody defining a molecule possibly identical to the p75 subunit of interleukin 2 receptor. J. Exp. Med. 169:1323-1332.

17. Yagita, H., M. Nakata, A. Azuma, T. Nitta, T. Takeshita, K. Sugamura, and $K$. Okumura. 1989. Activation of peripheral blood T cells via the $p 75$ interleukin 2 receptor. J. Exp. Med. 170:1445-1450.

18. Ohashi, Y., T. Takeshita, K. Nagata, S. Mori, and K. Sugamura. 1989. Differential expression of the interleukin 2 receptor subunits p55 and p75 on various populations of primary peripheral blood mononuclear cells. J. Immunol. 143:3548-3555.

19. Allouche, M., Y. Sahraoui, Y. Augery-Bourget, Y. Ohashi, K. Sugamura, C. Jasmin, and V. Georgoulias. 1989. Presence of a p70 IL-2-binding peptide on leukemic cells from various hemopoietic lineages. J. Immunol. 143:2223-2229.

20. Tsudo, M. F. Kitamura, and M. Miyasaka. 1989. Characterization of the interleukin 2 receptor $\beta$ chain using three distinct monoclonal antibodies. Proc. Natl. Acad. Sci. USA. 86:1982-1986.

21. Nakamura, Y., T. Inamoto, K. Sugie, H. Masutani, T. Shindo, Y. Tagaya K. Ozawa and J. Yodoi. 1989. Mitogenicity and down-regulation of high affinity interleukin 2 receptor by YTA-1 and YTA-2, monoclonal antibodies that recognize $75 \mathrm{kD}$ molecules on human large granular lymphocytes. Proc. Natl. Acad. Sci. USA. 86:1318-1322.

22. Burdach, S., and L. Levitt. 1987. Receptor-specific inhibition of bone marrow erythropoiesis by recombinant DNA-derived IL-2. Blood. 69:13681375 .

23. Rosenberg, S., E. Grimm, M. McGrogan, M. Doyle, E. Kawasaki, K Koths, and D. Mark. 1984. Biological activity of recombinant human interleukin 2 produced in Escherichia coli. Science (Wash. DC). 223:1412-1415.

24. Levitt, L., T. Kipps, E. Engleman, and P. Greenberg. 1985. Human bone marrow and peripheral blood $\mathrm{T}$ lymphocyte depletion: efficacy and effects of both $\mathrm{T}$ cells and monocytes on growth of hematopoietic progenitors. Blood. 65:663679.

25. Owen, C. 1989. Magnetic cell sorting using colloidal protein-magnetite. $J$ Immunogenetics. 16:117-123.

26. Siegel, J., M. Sharon, P. Smith, and W. Leonard. 1987. The IL-2 receptor $\beta$ chain (p70): role in mediating signals for LAK, NK and proliferative activities. Science (Wash. DC). 238:75-78.

27. Robb, R., W. Greene, and C. Rusk. 1984. Low and high affinity cellular receptors for interleukin 2. Implications for the level of Tac antigens. J. Exp. Med. 160:1126-1146.

28. Berger, $S$, and C. Birkenmeier. 1979. Inhibition of intractable nucleases with ribonucleoside-vanadyl complexes: isolation of messenger ribonucleic acid from resting lymphocytes. Biochemistry. 18:5143-5149.

29. Berger, S., and A. Kimmel. 1987. Guide to molecular cloning techniques. Methods Enzymol. 152:227-234.

30. Chomczynski, P., and N. Sacchi. 1987. Single-step method of RNA isolation by acid guanidinium thiocyanate-phenol-chloroform extraction. Anal. Biochem. 162:156-159.

31. Lee, F., T. Yokota, T. Otsuka, L. Gemmell, N. Larson, J. Luh, K. Arai, and D. Rennick. 1985. Isolation of cDNA for a human granulocyte-macrophage colony stimulating factor by functional expression in mammalian cells. Proc. Natl. Acad. Sci. USA. 82:4360-4364.

32. Gray, P., D. Leung, D. Pennica, E. Yelverton, R. Najaraian, C. Simonsen, R. Derynck, P. Sherwood, D. Wallace, S. Berger, A. Levinson, and D. Goeddel. 1982. Expression of human immune interferon cDNA in E. coli and monkey cells. Nature (Lond.). 295:503-508.

33. Melton, D., P. Krieg, M. Rebagliati, T. Maniatis, K. Zinnn, and M. Green. 1984. Efficient in vitro synthesis of biologically active RNA and RNA hybridiza- 
tion probes from plasmids containing a bacteriophage SP6 promoter. Nucleic Acids Res. 12:7035-7056.

34. Otsuka, T., A. Miyajima, N. Brown, K. Otsu, J. Abrams, S. Saeland, C. Caux, R. de Wall Malefijt, J. De Vries, P. Meyerson, K. Yokota, L. Gemmel, D. Rennick, and F. Lee. 1988. Isolation and characterization of an expressible cDNA encoding human IL-3. J. Immunol. 140:2288-2295.

35. Brenner, M., I. Trowbridge, and J. Strominger. 1985. Crosslinking of human $\mathrm{T}$ cell receptor proteins: association between the $\mathrm{T}$ cell idiotype $\beta$ subunit and the T3 glycoprotein heavy subunit. Cell. 40:183-190.

36. Dukovich, M., Y. Wano, B.-T. Le Thi, P. Katz, B. Callen, J. Kerhl, and W. Greene. 1987. A second human interleukin 2 binding protein that may be a component of high affinity IL-2 receptors. Nature (Lond.). 327:518-522.

37. Phillips, J., T. Takeshita, K. Sugamura, and L. Lanier. 1989. Activation of natural killer cells via the p75 interleukin 2 receptor. J. Exp. Med. 170:291-296.

38. Levitt, L., A. Nagler, F. Lee, F. J. Abrams, M. Shatsky, and D. Thompson 1991. Production of GM-CSF by human natural killer (NK) cells: modulation by the p70 IL-2 receptor and the CD2 (erythrocyte rosette) receptor. J. Clin. Invest. In press.

39. Sharon, M., J. Siegel, G. Tosato, J. Yodoi, T. Gerrard, and W. Leonard.
1988. The human interleukin 2 receptor $\beta$ chain (p70). Direct identification, partial purification, and patterns of expression on peripheral blood mononuclear cells. J. Exp. Med. 167:1265-1270.

40. Romain, P., and S. Schlossman. 1984. Human T lymphocyte subsets: functional heterogeneity and surface recognition structures. J. Clin. Invest. 74:1559-1565.

41. Mills, G., C. May, M. McGill, M. Fung, M. Baker, R. Sutherland, and W. Greene. 1990. Interleukin 2-induced tyrosine phosphorylation. J. Biol. Chem. 265:3561-3567.

42. Mills, G., and C. May. 1987. Binding of interleukin 2 to its 75-kDa intermediate affinity receptor is sufficient to activate $\mathrm{Na}+/ \mathrm{H}+$ exchange. J. Immunol. 139:4083-4087.

43. Rubin, L., G. Hoekzema, D. Nelson, W. Greene, and G. Jay. 1987. Reconstitution of a functional interleukin 2 receptor in a nonlymphoid cell. $J$. Immunol. 139:2355-2360.

44. Robb, R., C. Rusk, J. Yodoi, and W. Greene. 1987. An interleukin 2 binding molecule distinct from the Tac protein: analysis of its role in formation of high affinity receptors. Proc. Natl. Acad. Sci. USA. 84:2002-2006. 